ESRI

SURVEY AND STATISTICAL

REPORT SERIES NUMBER 85

APRIL 2020

\title{
ESSENTIAL EMPLOYEES DURING THE COVID-19 CRISIS
}

PAUL REDMOND AND SEAMUS MCGUINNESS

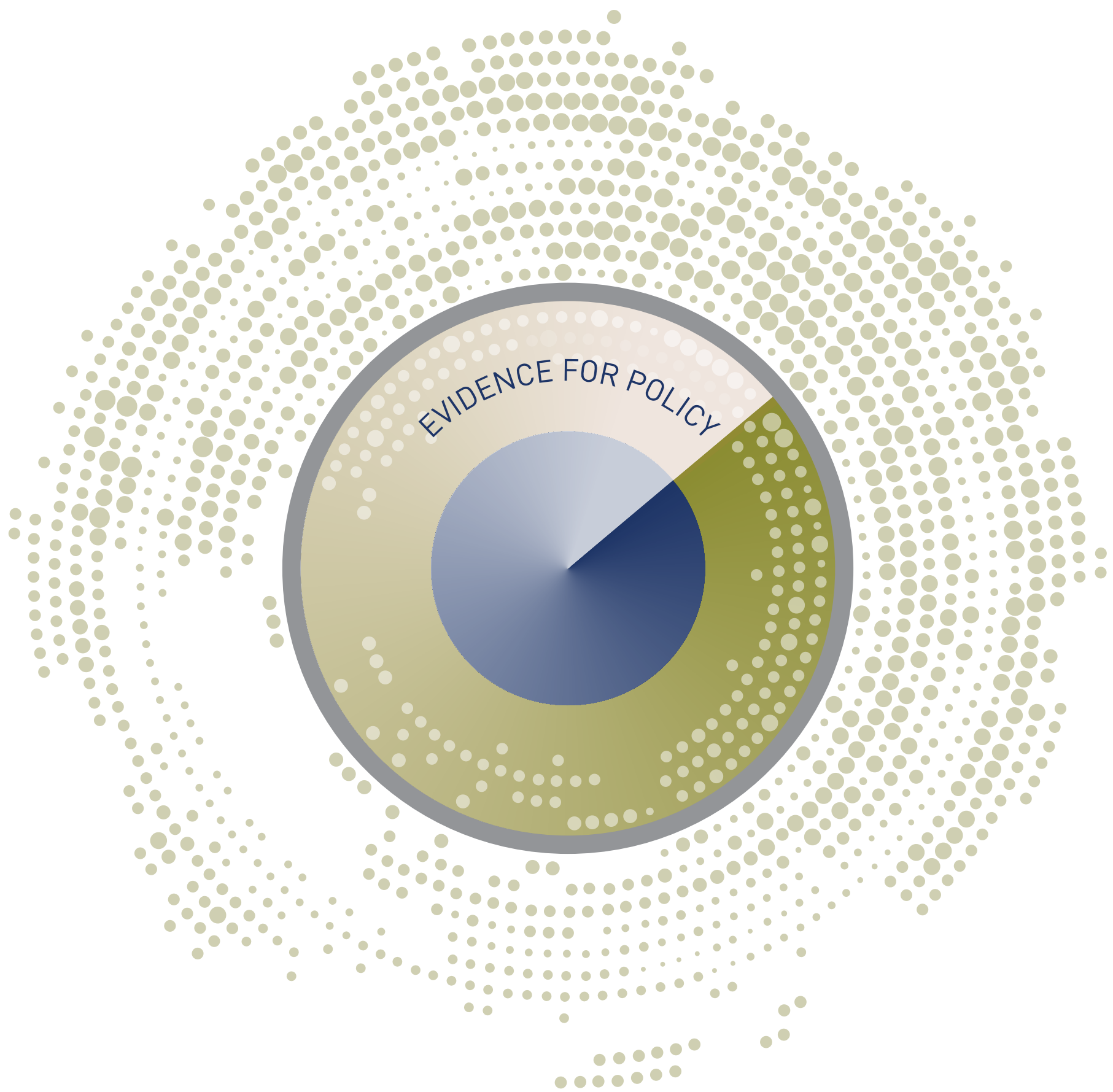




\section{ESSENTIAL EMPLOYEES DURING THE COVID-19 CRISIS}

Paul Redmond

Seamus McGuinness

April 2020

\section{ESRI SURVEY AND STATISTICAL REPORT SERIES}

\section{NUMBER 85}

Available to download from www.esri.ie

(C) The Economic and Social Research Institute

Whitaker Square, Sir John Rogerson's Quay, Dublin 2

ISBN 978-0-7070-0520-1

DOI https://doi.org/10.26504/sustat85.pdf

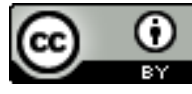

This Open Access work is licensed under a Creative Commons Attribution 4.0 International License (https://creativecommons.org/licenses/by/4.0/), which permits unrestricted use, distribution, and reproduction in any medium, provided the original work is properly credited. 


\section{ABOUT THE ESRI}

The mission of the Economic and Social Research Institute is to advance evidencebased policymaking that supports economic sustainability and social progress in Ireland. ESRI researchers apply the highest standards of academic excellence to challenges facing policymakers, focusing on 12 areas of critical importance to 21st Century Ireland.

The Institute was founded in 1960 by a group of senior civil servants led by $\mathrm{Dr}$ T. K. Whitaker, who identified the need for independent and in-depth research analysis to provide a robust evidence base for policymaking in Ireland.

Since then, the Institute has remained committed to independent research and its work is free of any expressed ideology or political position. The Institute publishes all research reaching the appropriate academic standard, irrespective of its findings or who funds the research.

The quality of its research output is guaranteed by a rigorous peer review process. ESRI researchers are experts in their fields and are committed to producing work that meets the highest academic standards and practices.

The work of the Institute is disseminated widely in books, journal articles and reports. ESRI publications are available to download, free of charge, from its website. Additionally, ESRI staff communicate research findings at regular conferences and seminars.

The ESRI is a company limited by guarantee, answerable to its members and governed by a Council, comprising 14 members who represent a cross-section of ESRI members from academia, civil services, state agencies, businesses and civil society. The Institute receives an annual grant-in-aid from the Department of Public Expenditure and Reform to support the scientific and public interest elements of the Institute's activities; the grant accounted for an average of 30 per cent of the Institute's income over the lifetime of the last Research Strategy. The remaining funding comes from research programmes supported by government departments and agencies, public bodies and competitive research programmes.

Further information is available at www.esri.ie 


\section{THE AUTHORS}

Seamus McGuinness is a Research Professor at the Economic and Social Research Institute (ESRI) and an Adjunct Professor at Trinity College Dublin (TCD). Paul Redmond is a Research Officer at the ESRI and an Adjunct Assistant Professor at TCD.

\section{ACKNOWLEDGEMENTS}

We are grateful to Alan Barrett, Karina Doorley and Helen Russell for providing comments on an earlier draft, and to the ISSDA for providing access to the Labour Force Survey data.

This report has been accepted for publication by the Institute, which does not itself take institutional policy positions. The report has been peer reviewed prior to publication. The authors are solely responsible for the content and the views expressed. 


\section{TABLE OF CONTENTS}

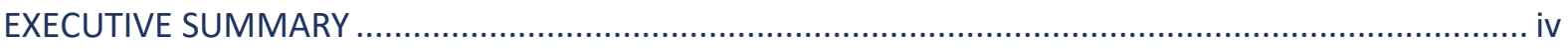

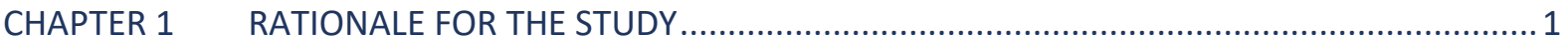

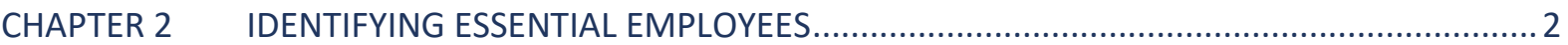

CHAPTER 3 THE DISTRIBUTION OF ESSENTIAL WORKERS IN IRELAND .................................... 4

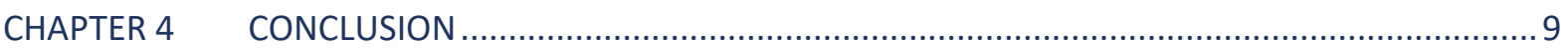

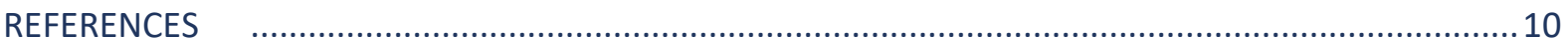

\section{LIST OF TABLES}

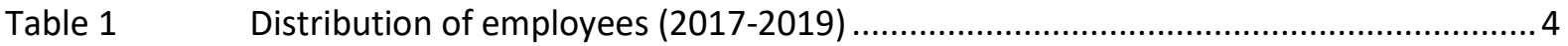

Table 2 Distribution of employees by region $(2017-2019)$.............................................. 5

Table 3 Family Composition of Essential Employees (2017-2019) ...................................5

Table $4 \quad$ Age of Youngest Child of Essential Employees (2017-2019) ................................. 6

\section{LIST OF FIGURES}

Figure $1 \quad$ Family Composition by Employee Group .......................................................6

Figure $2 \quad$ Age of Youngest Child of Essential Employees..................................................... 


\section{EXECUTIVE SUMMARY}

\section{Summary of main findings}

- In this report, we use Irish Labour Force Survey data to profile the characteristics of essential workers. We pay particular attention to the family structure, such as whether the employee has children and the age of those children. Given the closure of schools and crèches, this will provide insight into the potential challenges faced by those who are combining work with family responsibilities.

- We identify essential employees based on the official published list of essential workers that was published by the Irish Government on 28 March 2020. ${ }^{1}$ By combining sector and occupation codes, we identify seven categories of essential employees: Health Professionals (including, among others, doctors and nursing professionals); Health Associate Professionals (including, among others, medical technicians, ambulance workers and community health workers); Other Health Employees (including, among others, health workers in hospitals and nursing care facilities); Armed Forces (including all members of the armed forces); Defence and Public Administration (including, among others, police officers, prison guards and firefighters); Retail Sales Workers (including, among others, sales assistants and cashiers); Transport Operatives (including, among others, train, bus, taxi and tram drivers).

- While we endeavour to include as many essential employees as possible, based on the official Government guidance, we face some data constraints. As such, the groups we identify are not an exhaustive list of essential employees.

- The essential workers we identify account for 22 per cent of all employees in Ireland. Retail employees are the largest group of essential workers at seven per cent of all employees. However, we note that this group may be the least precisely identified group. In addition to essential retail workers, it will include retail employees in sectors that have closed. We discuss the difficulties in precisely identifying these employees in the main text.

- Health Professionals and Health Associate Professionals combined account for approximately 7 per cent of employees, similar to the number of Retail employees. Other Health Employees account for 5 per cent, and Transport workers account for 1.5 per cent of all employees. Armed Forces and Defence employees make up just over 1 per cent of all employees. 
- There exists no substantial regional variation in either the overall incidence or composition of essential workers across Ireland.

- Just over half of all essential employees have children: 43 per cent are part of a couple with children while 9 per cent are lone parents. Approximately 16 per cent of essential workers are in couples with no children, 18 per cent live with their parents, while 14 per cent do not live with any family members.

- The rate of lone parenthood is higher among essential employees (9 per cent) compared to other employees ( 5 per cent). This is primarily driven by a high rate of lone parent employees in the Other Health Employee group, at 14 per cent.

- Of those essential workers with children, approximately two-thirds have a youngest child aged 14 or below.

- Essential employees in Defence, Armed Forces and Health Professionals, are most likely to have very young children (aged 0-5 years).

- Of all essential employees who have children and live with a partner, approximately 80 per cent have a partner who also works. Approximately 20 per cent have a partner who is also an essential employee. However, this statistic is much higher for Defence (32 per cent) and Armed Forces (26 per cent) employees.

- The majority (almost 70 per cent) of essential employees are female, which is driven by the high numbers of females in the three health groupings and in Retail. Transport, Armed Forces and Defence, on the other hand, are predominantly occupied by males.

- Approximately 14 per cent of essential employees are non-Irish nationals. The groups with the highest concentration of non-Irish nationals are Transport (18 per cent) and Retail (16 per cent).

- Many essential workers are concentrated in lower paid occupations, such as Retail and Other Health Employees. The capacity of such employees to pay for additional childcare services is likely to be substantially constrained. 


\section{CHAPTER 1}

\section{Rationale for the study}

The Covid-19 health crisis has led to unprecedented disruption to the economy and society. A significant share of employees are no longer working due to the widespread shutdown of certain sectors. Vast numbers of other employees find themselves working from home, in an effort to comply with social distancing measures. However, a large number of employees perform critical functions that are key to keeping our health system, economy and society functioning during the crisis. For these essential employees, working from home is not an option. With schools, crèches and universities closed, this raises particular challenges for these types of workers, especially those with family caring requirements. In this report, we use Irish Labour Force Survey data to profile the characteristics of essential workers. We pay particular attention to the family structure, such as whether the employee has children and the age of those children, in order to evaluate the potential challenges faced by those who are combining work with family responsibilities. We also examine the status of the spouses of essential workers. For example, with the closure of schools and crèches, if both parents are essential employees, this may present particular challenges.

It is important to note from the outset that the groups we focus on are not an exhaustive list of essential workers. We identify employees based on the official published list of essential workers that was published by the Irish Government on 28 March 2020. However, data constraints prevent us from identifying all essential employees. 


\section{CHAPTER 2}

\section{Identifying essential employees}

We combine sector codes with occupation codes to identify essential employees using Irish Labour Force Survey (LFS) data for the years 2017 to 2019. We use the Anonymised Data File (AMF) for the LFS, which is accessed via the Irish Social Science Data Archive (ISSDA). Below is a list of the essential employee groups that we identify.

\section{- Health Professionals}

We combine the Health NACE sector with the ISCO Professionals category to examine Health Professionals. This group will include, but may not be limited to, medical doctors, nursing and midwifery professionals, paramedical practitioners, dentists, pharmacists and social work professionals.

\section{- Health Associate Professionals}

We combine the Health NACE sector with the ISCO Associate Professionals category to examine Health Associate Professionals. This group will include, but may not be limited to, medical and pharmaceutical technicians, nursing and midwifery associate professionals, dental assistants, community health workers, medical assistants, ambulance workers and social work associate professionals.

\section{- Other Health Employees}

We combine the Health NACE sector with the ISCO Services and Sales category to examine Other Health Employees. This group will include, but may not be limited to, health care assistants in hospitals, clinics and residential nursing care facilities. It will also include home-based personal care workers as well as other health services workers, such as hospital orderlies, pharmacy aides and medical imaging assistants.

\section{- Armed Forces}

We combine the Public Administration and Defence NACE sector with the ISCO Armed Forces category. This includes all jobs held by members of the armed forces.

\section{- Defence and Public Administration}

We combine the Public Administration and Defence NACE sector with the ISCO Services and Sales category to examine Defence and Public Administration. This will include, but may not be limited to, police officers, prison guards and fire fighters. 
- Retail Sales

We combine the Wholesale and Retail Trade NACE sector with the ISCO Services and Sales category to examine Retail Sales. This will include, but may not be limited to, shop sales assistants, shop keepers, shop supervisors, cashiers, service station attendants and food service counter attendants. Note that many retail outlets have been forced to close down during the Covid-19 crisis, while others remain open. Given our broad categories, we cannot precisely distinguish between the two. Therefore, while this category will include employees in so called 'essential retail services', it will also include employees in retail outlets that have been forced to close down.

- Transport Operatives

We combine the Transport, Storage and Communications NACE sector with the ISCO Plant and Machine Operators category to examine Transport employees. These will include, but may not be limited to, bus, tram, train, taxi and lorry drivers.

- Other Employees

We sometimes refer to 'other employees'. These are employees not contained in any of the six categories above. 


\section{CHAPTER 3}

\section{The distribution of essential workers in Ireland}

Table 1 shows the distribution of employees by category. Essential workers account for just over 22 per cent of employees in Ireland. Retail workers are the largest group of essential workers at 7 per cent of all employees, followed by Health Professionals and Other Health workers, who each account for approximately 5 per cent of all employees. Health Associate Professionals, Transport workers and Defence and Public Administration workers account for approximately 1 per cent of all employees, with Armed Forces making up 0.3 per cent of total employees.

Table 2 shows the distribution of employees across three regions: North and West; South; East and Midland. There exists no substantial regional variation in the distribution of essential employees across regions.

TABLE $1 \quad$ DISTRIBUTION OF EMPLOYEES (2017-2019)

\begin{tabular}{|l|c|}
\hline \multicolumn{1}{|c|}{ Employee Group } & Per Cent \\
\hline Essential Employees & \\
\hline Health Professionals & 5.47 \\
\hline Health Associate Professionals & 1.46 \\
\hline Other Health Employees & 5.09 \\
\hline Armed Forces & 0.30 \\
\hline Defence and Public Administration & 0.98 \\
\hline Retail Sales & 7.17 \\
\hline Transport & 1.54 \\
\hline Total Essential Employees & $\mathbf{2 2 . 0 1}$ \\
\hline Other employees & $\mathbf{7 7 . 9 8}$ \\
\hline
\end{tabular}

Sources: Irish Labour Force Survey, 2017 to 2019. Statistics based on a sample size of 158,885 employees (includes 34,990 essential employees and 123,895 other employees). 


\begin{tabular}{|l|c|c|c|}
\hline & \multicolumn{3}{|c|}{ Region } \\
\hline Health Professionals & NW & S & EM \\
\hline Health Associate Professionals & 5.91 & 5.40 & 5.46 \\
\hline Other Health Employees & 1.69 & 1.49 & 1.36 \\
\hline Armed Forces & 6.40 & 5.64 & 4.49 \\
\hline Defence and Public Administration & 0.22 & 0.32 & 0.33 \\
\hline Retail Sales & 0.80 & 0.87 & 1.14 \\
\hline Transport & 7.85 & 7.86 & 6.81 \\
\hline Other Employees & 1.54 & 1.41 & 1.31 \\
\hline
\end{tabular}

Sources: Irish Labour Force Survey, 2017 to 2019. Statistics based on a sample size of 153,866 employees (34,096 essential employees and 119,770 other employees). NW refers to North and West (Cavan, Donegal, Leitrim, Monaghan, Sligo, Galway, Mayo and Roscommon). S refers to South (Clare, Limerick, Tipperary, Carlow, Kilkenny, Waterford, Wexford, Cork and Kerry). EM refers to Eastern and Midland (Dublin, Kildare, Meath, Wicklow, Louth, Laois, Longford, Offaly, Westmeath). Sample size is slightly smaller than that in Table 1 due to some missing region data.

Table 3 examines the family composition of essential employees to give us an indication of potential childcare requirements. Just over half of all essential workers have children; 44 per cent are part of a couple with children while 9 per cent are lone parents. Approximately 16 per cent of essential employees are in couples with no children, 18 per cent live with their parents and the remaining 14 per cent do not live with any other family members.

\begin{tabular}{|l|r|}
\hline \multicolumn{1}{|c|}{ Family Type } & Per Cent \\
\hline Couple (No Children) & 16 \\
\hline Couple (With Children) & 44 \\
\hline Lone Parent & 9 \\
\hline Living With Parent(S) & 18 \\
\hline Other Family & 14 \\
\hline
\end{tabular}

Sources: Irish Labour Force Survey, 2017 to 2019. Statistics based on a sample size of 34,990 essential employees.

Notes: The 'Other family' type refers to individuals who do not live with family. The 'Living with parent(s)' category consists of children of couples, as well as children of lone parents.

Figure 1 shows the family composition for each category of essential employees, as well as other employees. There are some important variations in terms of potential childcare requirements. In general, there is a higher incidence of lone parents (9 per cent) among essential employees, compared to 'other employees' ( 5 per cent). This is driven, to a large extent, by Other Health Employees, of which 14 per cent are lone parents. Retail Sales employees have a greater share of workers who live with parents or in couples with no children. However, this group also has a relatively high incidence of lone parents, at 9 per cent. 'Couples with children' is the most prevalent family group among all employee types. This 
family type is particularly high among Defence and Public Administration employees, at 65 per cent.

\section{FIGURE 1 FAMILY COMPOSITION BY EMPLOYEE GROUP}

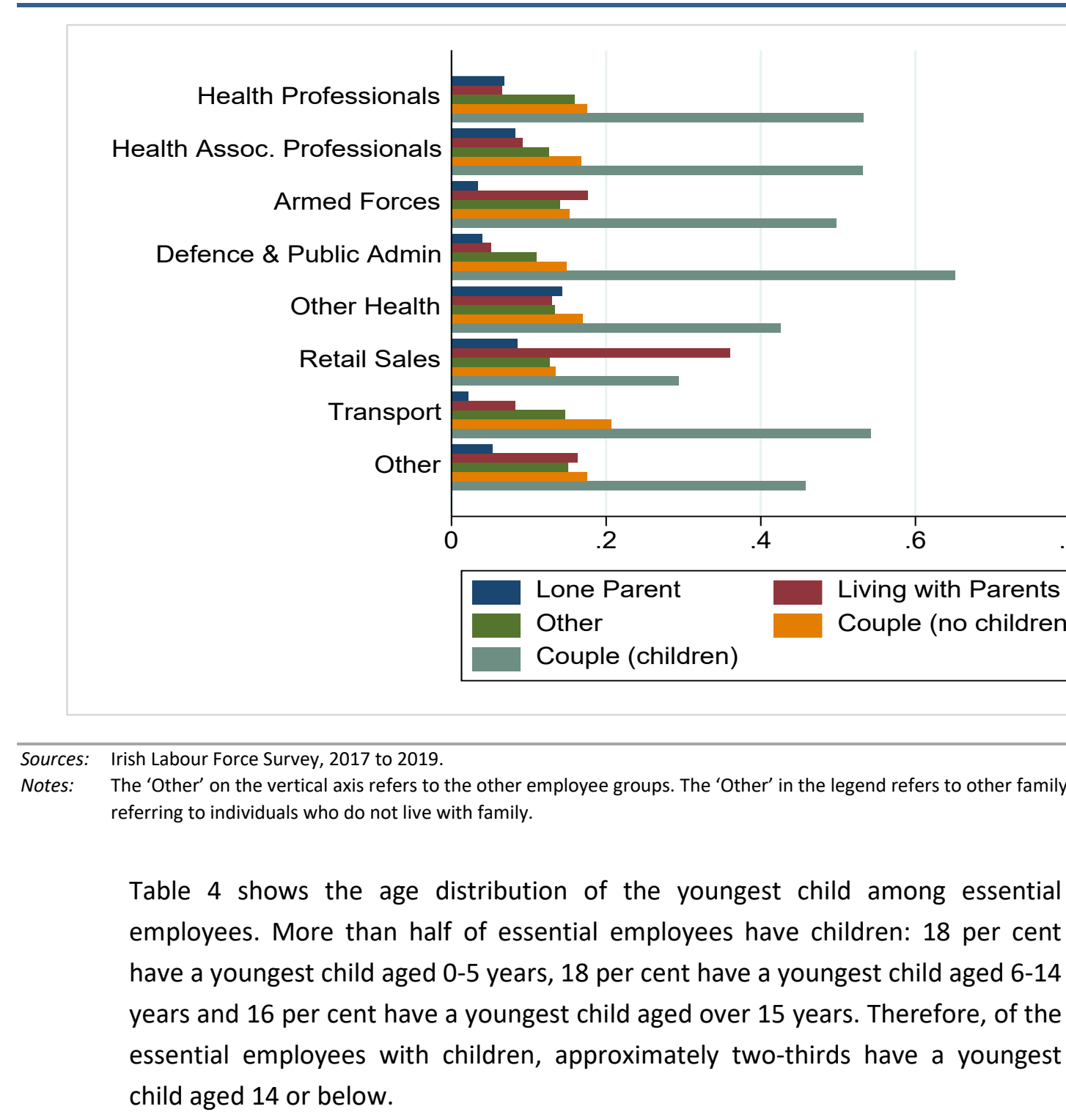

\begin{tabular}{|l|c|}
\hline Age of Youngest Child & Per Cent \\
\hline $\mathbf{0 - 5}$ years & 18 \\
\hline $\mathbf{6 - 1 4}$ years & 18 \\
\hline $\mathbf{1 5}+$ years & 16 \\
\hline No Children & 48 \\
\hline
\end{tabular}

Sources: Irish Labour Force Survey, 2017 to 2019.

Notes: Examines the age of youngest child among 34,990 essential employees. Of those with no children, 34 per cent are in couples, 38 per cent are children living with parents and 29 per cent are individuals not living with another family member.

Figure 2 shows the breakdown of youngest child age by employee group. Defence and Public Administration, Armed Forces and Health Professionals all have a 
relatively high incidence of very young children (aged 0-5 years). Retail employees are most likely to have no children, compared to all other groups.

\section{FIGURE 2 AGE OF YOUNGEST CHILD OF ESSENTIAL EMPLOYEES}

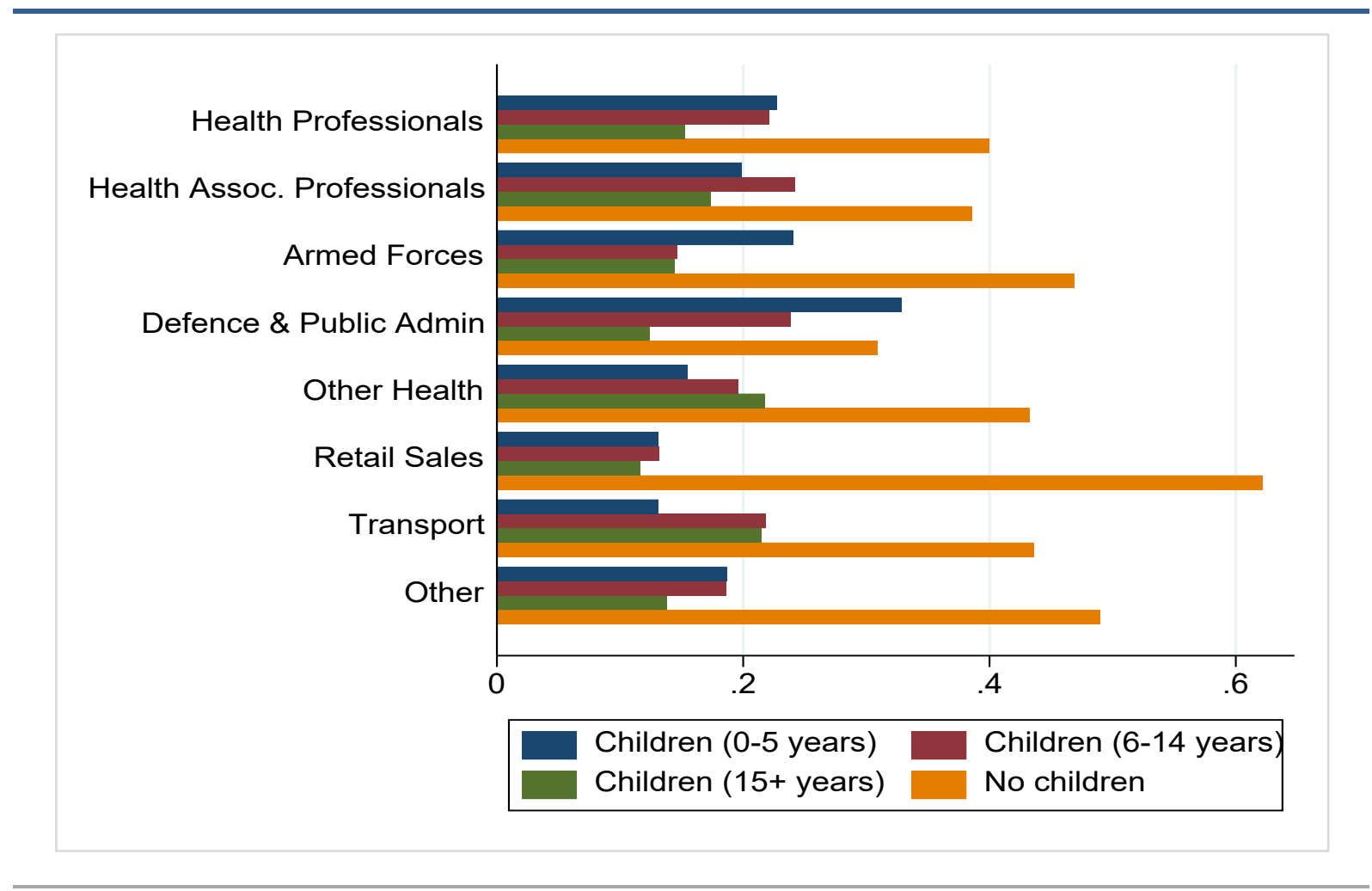

Sources: Irish Labour Force Survey, 2017 to 2019.

Regarding the gender of employees, the majority (almost 70 per cent) of essential employees are female. This reflects the very high percentage of females in the three health groupings ( 80 per cent) and Retail (70 per cent). However, the percentage of male employees in Transport, Armed Forces and Defence and Public Administration is 98 per cent, 94 per cent and 74 per cent respectively.

Approximately 14 per cent of essential employees are non-Irish nationals. The groups with the highest concentration of non-Irish nationals are Transport (18 per cent) and Retail (16 per cent). Approximately 14 per cent of Health employees are non-Irish nationals, while virtually all employees in Armed Forces and Defence and Public Administration are Irish nationals.

Finally, focusing on couples with children, we find that 80 per cent of essential employees have a partner that also works. Approximately 20 per cent have a partner who is also an essential employee. This statistic is much higher for Defence (32 per cent) and Armed Forces (26 per cent). Therefore, these households consist of two adults that are both essential employees, and must 
also care for children. Given school and crèche closures, balancing work and family may be particularly difficult for such households at this time.

Balancing family and work responsibilities against the backdrop of school closures will be an issue for other countries that adopt such measures to deal with the Covid-19 pandemic. Farquharson et al. (2020) examine key workers in the UK. Much of their analysis is consistent with our findings. For example, Farquharson et al. (2020) find that 42 per cent of key workers have a youngest child aged 16 or below. For Ireland, we found that 36 per cent of essential workers have a youngest child aged 14 or below. ${ }^{2}$ As in Ireland, Farquharson et al. (2020) also report a higher incidence of lone parents among key workers in the UK. In recognition of these challenges, the children of key workers in the UK are still eligible for childcare in schools, despite the schools being shut for other pupils. 


\section{CHAPTER 4}

\section{Conclusion}

The Covid-19 health crisis has led to widespread disruption to the Irish labour market and to society in general. Many employees are without jobs while many others work from home. On 28 March 2020, the Irish Government published a list of essential employees that are vital to the continued functioning of the economy and society. These employees cannot work from home. However, with school and crèche closures, many essential employees may face challenges in combining work and family responsibilities. This report examines the labour market composition of essential employees in Ireland, with a particular focus on childcare and family responsibilities. We find that essential workers make up around 20 per cent of all employees in Ireland. Just over half of all essential employees have children, consisting of 43 per cent that are part of a couple and 9 per cent that are lone parents. The incidence of lone parents, at 9 per cent, is higher among essential employees, compared to other employees where the incidence is 5 per cent. This is driven by a particularly high rate of lone parenthood among Other Health Employees, where 14 per cent are lone parents.

Of those essential employees with children, approximately two-thirds have a youngest child aged 14 or below. Employees in Defence, Armed Forces and Health Professionals are most likely to have a very young child (aged 0-5 years).

Of all essential employees who have children and live with a partner, approximately 80 per cent have a partner that also works. Approximately 20 per cent have a partner who is also an essential employee, with the rate being highest for Defence and Public Administration (32 per cent) and Armed Forces (26 per cent) employees.

The report highlights the fact that a substantial proportion of essential employees are likely to have significant childcare needs that will certainly have been intensified as a result of school closures. Unlike other countries, such as the UK, there has not yet been direct government provision for the childcare needs of essential employees in Ireland. Furthermore, given that many essential workers are concentrated in lower paid occupations, such as Retail and Other Health Employees, the capacity of many such employees to pay for additional childcare services is likely to be substantially constrained. Therefore, facilitating adequate childcare for these essential employees is critical to ensure that we can continue to respond to the crisis. 


\section{REFERENCE}

Farquharson, C., I. Rasul and L. Sibieta (2020). Key workers: Key facts and questions, London: Institute for Fiscal Studies. 
Whitaker Square,

Sir John Rogerson's Quay,

Dublin 2

Telephone +353 18632000

Email admin@esri.ie

Web www.esri.ie

Twitter @ESRIDublin

ISBN 978-0-7070-0520-1 